\title{
Five-Coordinate Zinc(II) Complex: Synthesis, Characterization, Molecular Structure, and Antibacterial Activities of Bis-[(E)-2- hydroxy- $N^{\prime}-\{1$-(4-methoxyphenyl)ethylidene $\}$ benzohydrazido] dimethylsulfoxidezinc(II) Complex
}

\author{
Zhi-Qiang Liu, ${ }^{1}$ Yoke Mooi Ng, ${ }^{2}$ Pei Jen Tiong, ${ }^{2}$ Ruwaida Asyikin Abu Talip, \\ Nornadia Jasin, ${ }^{2}$ Vivien Yi Mian Jong, ${ }^{3}$ and Meng Guan Tay ${ }^{2}$ \\ ${ }^{1}$ State Key Lab of Crystal Materials, Shandong University, Jinan 250100, China \\ ${ }^{2}$ Department of Chemistry, Faculty of Resource Science and Technology, Universiti Malaysia Sarawak, \\ 94300 Kota Samarahan, Sarawak, Malaysia \\ ${ }^{3}$ Center of Applied Sciences, Universiti Teknologi MARA, Kampus Kota Samarahan 2, 94300 Kota Samarahan, Sarawak, Malaysia \\ Correspondence should be addressed to Meng Guan Tay; mgtay@unimas.my
}

Received 14 March 2017; Accepted 26 April 2017; Published 15 June 2017

Academic Editor: Hakan Arslan

Copyright (C) 2017 Zhi-Qiang Liu et al. This is an open access article distributed under the Creative Commons Attribution License, which permits unrestricted use, distribution, and reproduction in any medium, provided the original work is properly cited.

The titled $\mathrm{Zn}$ (II) complex was synthesized by reacting the compound (E)-2-hydroxy- $N^{\prime}$-\{1-(4-methoxyphenyl)ethylidene\}benzohydrazide with zinc(II) acetate dihydrate in alkaline DMSO and ethanol solution under reflux condition for 28 hours. The resulting solid was filtered and recrystallized from the mixture of ethanol and DMSO. The hydrazone Schiff base and its $\mathrm{Zn}$ (II) complex were characterized using ${ }^{1} \mathrm{H},{ }^{13} \mathrm{C}$ NMR, FTIR, UV-Vis spectroscopy, and single crystal X-ray diffraction analysis. Meanwhile, their antibacterial activities were examined using disc diffusion method. The spectral studies showed that the hydrazone Schiff base underwent keto-enol tautomerization, forming a bidentate ligand (N,O) towards Zn(II) ion. Surprisingly, on top of the two hydrazone Schiff base molecules which coordinated to the $\mathrm{Zn}$ metal center, an additional DMSO molecule was found attached to the $\mathrm{Zn}$ metal center in the crystal data, resulting in a 5-coordinate distorted trigonal bipyramidal Zn(II) complex. Both hydrazone Schiff base and its $\mathrm{Zn}$ (II) complexes were found to exhibit low antibacterial activity even when the concentrations were increased to $800 \mathrm{ppm}$.

\section{Introduction}

Hydrazone Schiff base plays an important role in inorganic chemistry, as it can easily form stable complexes with most transition metal ions due to its ability to form keto-enol tautomerism (Figure 1) [1-4]. In coordination chemistry, the hydrazone Schiff base ligand normally presents in enol conformation in order to bind with the metal center through the nitrogen atom from imine moiety [5-7] and oxygen from hydroxyl group $[8,9]$.

Complexation with $\mathrm{Zn}(\mathrm{II})$ metal center usually results in complexes with 4-coordination number and a tetrahedral geometry. This is due to the fact that $\mathrm{Zn}$ is a late transition metal with full $d$ valence electrons, which means that a stable 18-electron complex can be formed through 4-coordination number with its ligands. Due to this reason, 5-coordinate $\mathrm{Zn}$ complex is considered unusual and expected to be unstable. Nevertheless, 5-coordinate $\mathrm{Zn}$ complexes were previously reported [10-14]. Similar to 4-coordinate $\mathrm{Zn}$ complexes, the common oxidation state for $\mathrm{Zn}$ ion in 5-coordinate $\mathrm{Zn}$ complexes is +2 ; however, the one reported by Song et al. is in 0 oxidation state [13]. In this paper, the synthesis (Scheme 1) and spectroscopic and crystallographic data of a 5-coordinate trigonal bipyramid bis-[(E)-2-hydroxy- $N^{\prime}$ \{1-(4-methoxyphenyl)ethylidene\}benzohydrazido] dimethylsulfoxidezinc(II) complex are reported. In addition, the antibacterial activities of both hydrazone Schiff base $\mathbf{L 1}$ and $\mathrm{Zn}$ (II) complex have also been examined. 


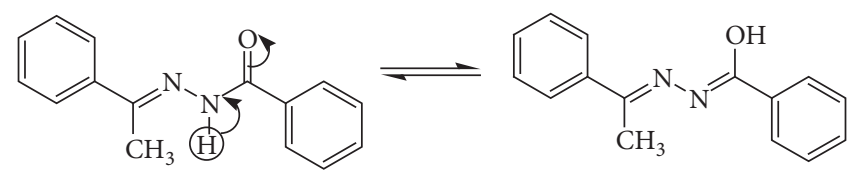

Keto form

Enol form

FIGURE 1: Keto-enol tautomerization of a hydrazone Schiff base compound.<smiles>COc1ccc(C(C)=NN=C(O)c2ccccc2O)cc1</smiles>

SCHEme 1: Synthetic pathway of L1 and its 5-coordinate $\mathrm{Zn}$ (II) complex.

\section{Experimental}

2.1. Equipment or Instrumentation. The IR spectra of $\mathbf{L} \mathbf{1}$ and the $\mathrm{Zn}$ (II) complex were recorded in $\mathrm{KBr}$ disks by using Thermo Scientific/Nicolet iS10 8001PC FTIR Spectrometer with the wavelength range from 400 to $4000 \mathrm{~cm}^{-1}$. Jasco/V$630 \mathrm{UV}$-visible spectrophotometer was used to record the electronic absorption spectra with DCM solvent. JEOL ECA$500 \mathrm{NMR}$ spectrometer with $500 \mathrm{MHz}$ was used to record all the ${ }^{1} \mathrm{H}$ and ${ }^{13} \mathrm{C}$ NMR spectra. ${ }^{1} \mathrm{H}$-NMR chemical shift was reported relative to TMS and referenced via residual proton NMR resonance of the appropriate deuterated solvent (DMSO- $\mathrm{d}_{6}: 2.50 \mathrm{ppm} ; \mathrm{CD}_{2} \mathrm{Cl}_{2}: 5.32 \mathrm{ppm}$ ). Stuart SMP3 Melting Point was used to measure the melting point of $\mathbf{L} \mathbf{1}$ and the $\mathrm{Zn}$ (II) complexes. The elemental analysis was conducted by using CHN Analyzer, Thermo-Flash EA 1112 series at the temperature up to $900^{\circ} \mathrm{C}$, and vanadium pentoxide was used as oxidizer to prevent inhibition caused by sulphur.

$\mathrm{X}$-ray measurements for the $\mathrm{Zn}$ complex were performed on a Bruker SMART diffractometer equipped with a graphite monochromated Mo $\mathrm{Ka}(\lambda=0.71073)$ radiation source and a CCD detector. The frame integration was performed using the program SAINT [15]. The structure was solved by direct method provided by the program package SHELXTL97 and refined a full matrix least square against F2 for all data [16]. All nonhydrogen atoms were refined anisotropically. All hydrogen atoms were introduced at idealized positions and were allowed to refine isotopically. Crystallographic data for $\mathrm{Zn}$ (II) complexes has been deposited in the Cambridge Crystallographic Data Centre CCDC number 1508885 . The data are available free of charge via https://www.ccdc.cam.ac.uk/data_request/cif (or from the CCDC, 12 Union Road, Cambridge CB2 1EZ, UK; +44 1223 336033; e-mail: deposit@ccdc.cam.ac.uk).

2.2. Antibacterial Study of the Compounds. The antibacterial study was carried out on hydrazone Schiff base $\mathbf{L 1}$ and its $\mathrm{Zn}$ (II) complex using disc diffusion method [17]. One colony of Bacillus cereus ATCC 33019 from a streak plate was inoculated in $20 \mathrm{~mL}$ of LB broth. After 16 hours of incubation, the optical density of the inoculums was measured and further diluted to achieve McFarland standard of 0.5. Using sterile cotton swab, agar plate was uniformly swabbed with diluted inoculums of the bacteria. After that, sterile filter papers $(6 \mathrm{~mm})$ which were impregnated with different concentrations (i.e., 200, 400, and 800 ppm using DCM as 


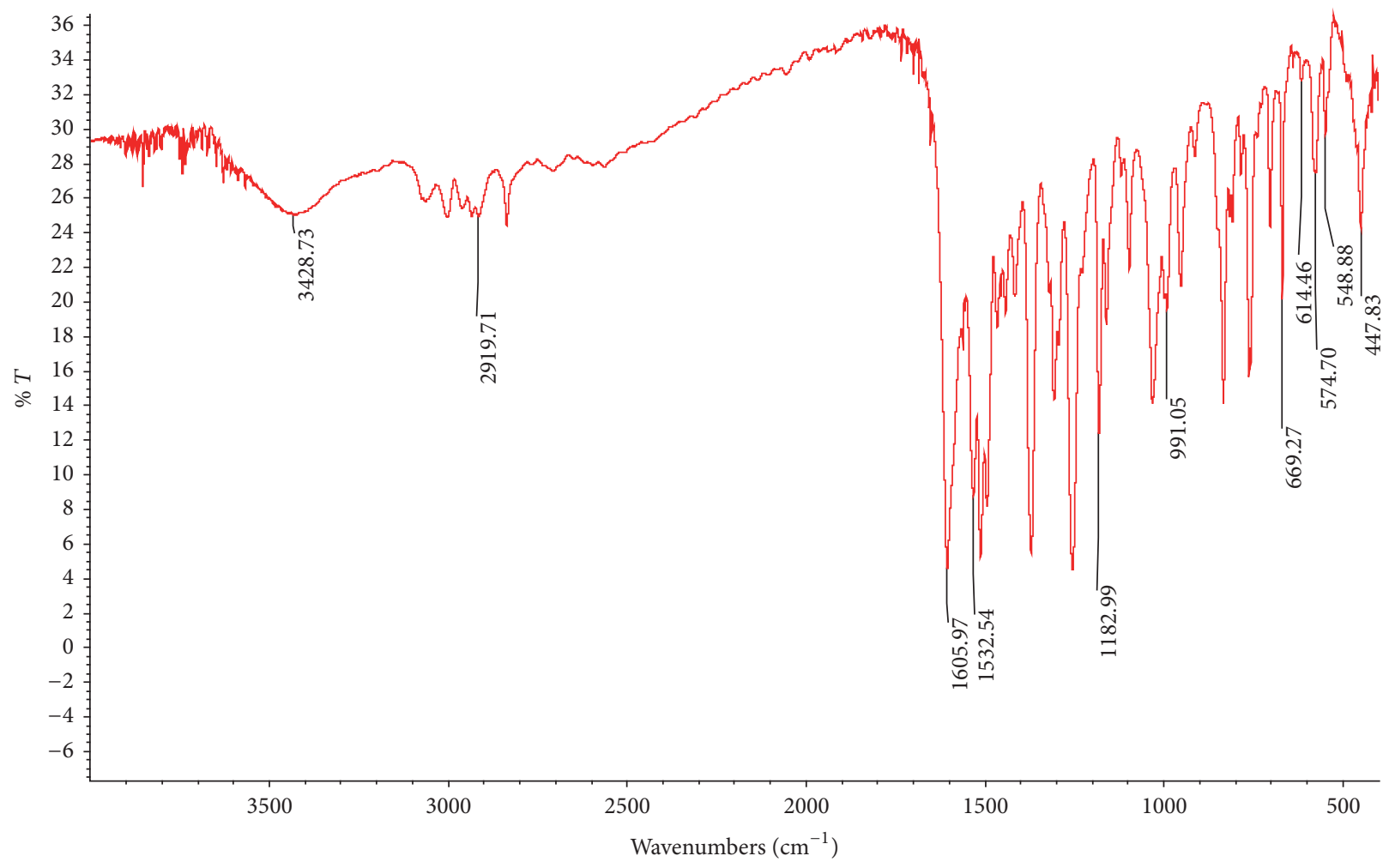

FIgURE 2: IR spectrum of the $\mathrm{Zn}(\mathrm{II})$ complex.

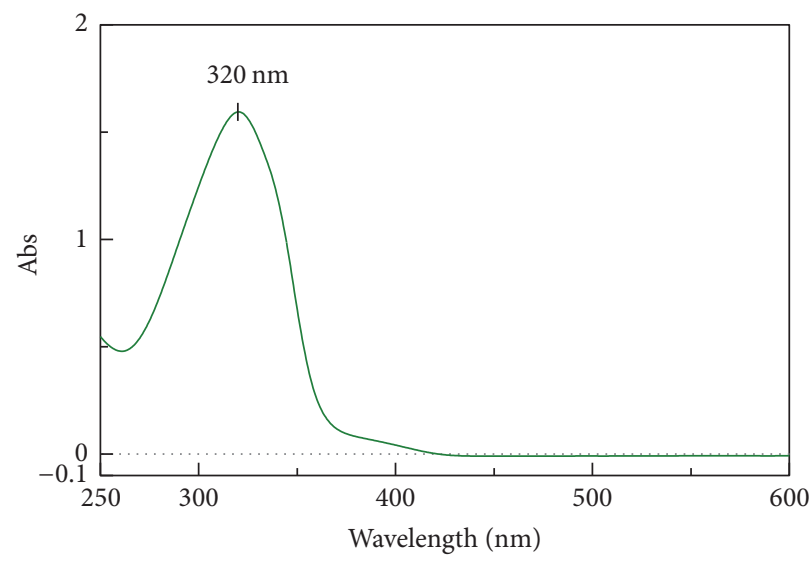

(a)

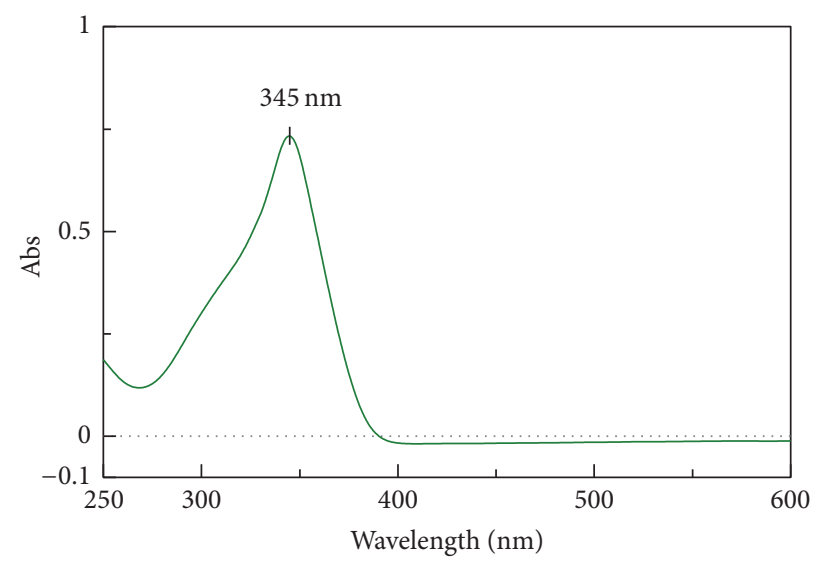

(b)

Figure 3: UV-Vis spectra of (a) L1 and (b) its $\mathrm{Zn}$ (II) complex.

the solvent) of $\mathbf{L} \mathbf{1}$ and its $\mathrm{Zn}$ (II) complex were placed on the agar. The inhibitory zones in millimeters were measured after 24 hours of incubation. Similar procedures were conducted in another set for Escherichia coli ATCC 35150. All the antibacterial assays were performed in triplicate.

\subsection{Synthesis}

2.3.1. Preparation of (E)-2-Hydroxy- $\mathrm{N}^{\prime}$-(1-(4-methoxyphenyl) ethylidene)benzohydrazide (L1) [18]. Salicylhydrazide (1.522 g, $10 \mathrm{mmol}$ ) was dissolved in $25 \mathrm{~mL}$ of ethanol and added to a round bottom flask with constant stirring. An ethanolic solution of $4^{\prime}$-methoxyacetophenone $(1.501 \mathrm{~g}, 10 \mathrm{mmol})$ was then added dropwise. The mixture was refluxed for 24 hours followed by cooling to room temperature. The precipitate which appeared as white crystals was filtered, washed with ethanol, and dried in vacuo over silica gel. Yield: $2.14 \mathrm{~g}, 75.4 \%$. M.P.: $210.2-215.7^{\circ} \mathrm{C}$. Anal. Calcd for $\mathrm{C}_{16} \mathrm{H}_{16} \mathrm{~N}_{2} \mathrm{O}_{3}$ : C, 67.09; $\mathrm{H}$, 5.45; N.8.78; Found: C, 67.59; H, 5.67; N, 9.85\%. IR (KBr disk, $\mathrm{cm}^{-1}$ ): $3435(\mathrm{~s}), 3270(\mathrm{~s}), 1605(\mathrm{~s}), 982(\mathrm{~m}) .{ }^{1} \mathrm{H}$ NMR (DMSO$\left.\mathrm{d}_{6}, \delta\right): 11.81(\mathrm{~s}, 1 \mathrm{H}, \mathrm{N}-\mathrm{H}), 11.28(\mathrm{~s}, 1 \mathrm{H}, \mathrm{Ar}-\mathrm{OH}), 7.99(\mathrm{~d}, 1 \mathrm{H}, J=$ $8 \mathrm{~Hz}, \mathrm{Ar}-\mathrm{H}), 7.82(\mathrm{~d}, 2 \mathrm{H}, J=8 \mathrm{~Hz}, \mathrm{Ar}-\mathrm{H}), 7.42(\mathrm{t}, 1 \mathrm{H}, J=8 \mathrm{~Hz}$, Ar- $\mathrm{H}), 6.97$ (m, 4H, Ar-H), $3.81\left(\mathrm{~s}, 3 \mathrm{H}, \mathrm{OCH}_{3}\right), 2.30(\mathrm{~s}, 3 \mathrm{H}$, $\left.\mathrm{H}_{3} \mathrm{C}-\mathrm{C}=\mathrm{N}\right) .{ }^{13} \mathrm{C}$ NMR $\left(\mathrm{DMSO}^{-} \mathrm{d}_{6}, \delta\right): 162.08,160.40,156.66$, 


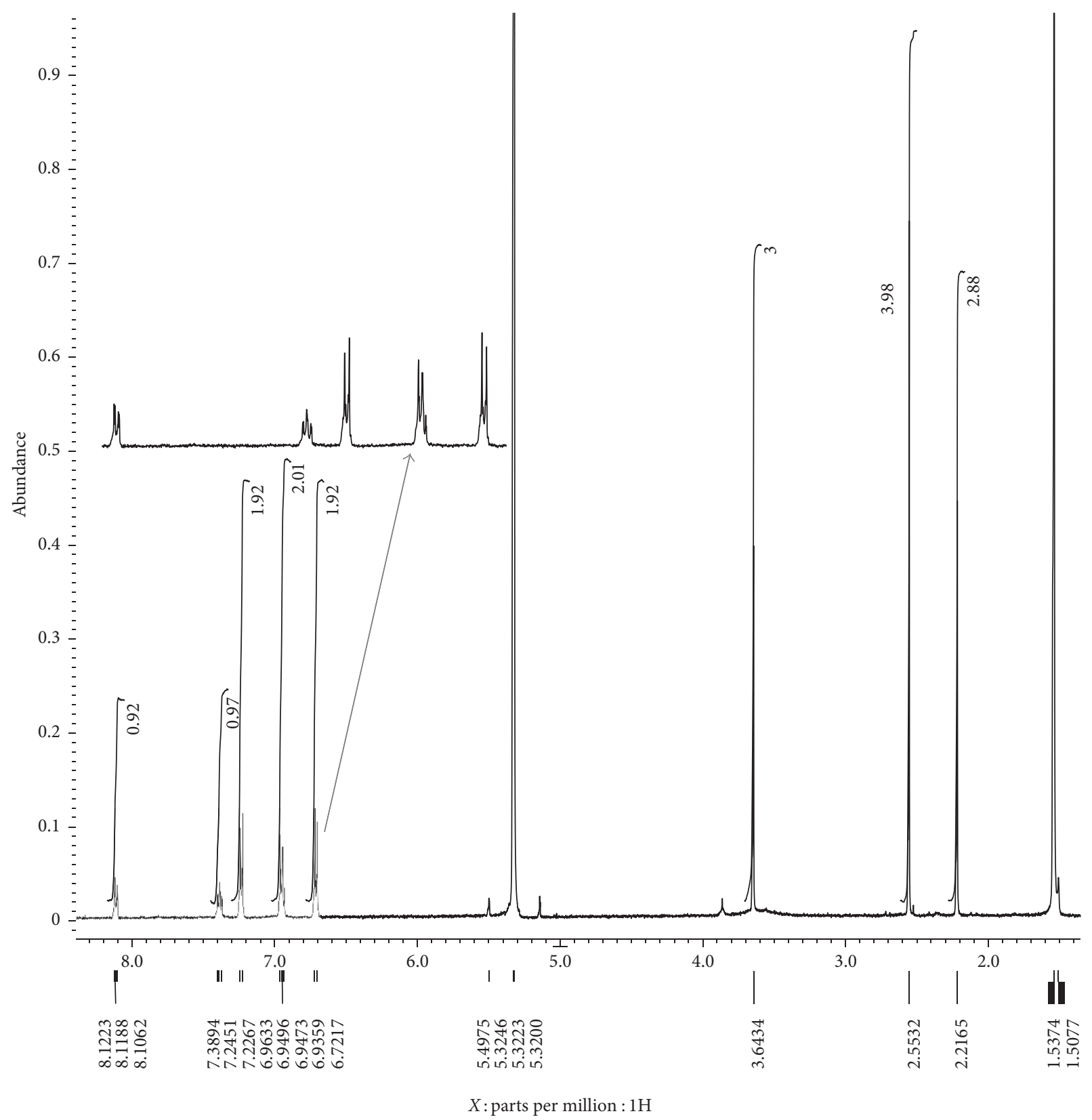

FIgURE $4:{ }^{1} \mathrm{H}$ NMR spectrum of the $\mathrm{Zn}$ (II) complex.

$152.35,113.76,116.89,117.84,119.64,127.98,130.30,130.46$, $133.29,152.35,55.24,13.78$. UV-Vis [DCM, $\lambda_{\max }$ ]: $320 \mathrm{~nm}$.

\subsubsection{Preparation and Crystallization of Bis-[(E)-2-hydroxy-} $N^{\prime}$-\{1-(4-methoxyphenyl)ethylidene\}benzohydrazido]dimethylsulfoxidezinc(II) Complex. The compound (E)-2-hydroxy$N^{\prime}$-(1-(4-methoxyphenyl)ethylidene)benzohydrazide ( $0.142 \mathrm{~g}$, $0.5 \mathrm{mmol}$ ) was dissolved in $5 \mathrm{~mL}$ of DMSO in a round bottom flask with constant stirring. Potassium hydroxide, $\mathrm{KOH}(0.056 \mathrm{~g}, 1 \mathrm{mmol})$, was dissolved in $10 \mathrm{~mL}$ of absolute ethanol and added to the flask dropwise. The resulting mixture was refluxed for 1.5 hours, followed by dropwise addition of zinc(II) acetate dihydrate $(0.11 \mathrm{~g}, 0.5 \mathrm{mmol})$ solution in $5 \mathrm{~mL}$ DMSO. The mixture turned from yellow to golden yellow color. After being refluxed for 28 hours, the solution was cooled to room temperature followed by filtration and recrystallization from the mixture of DMSO and absolute ethanol. A yellow crystal was obtained after one week, which was then filtered and washed with DMSO. Yield: $0.17 \mathrm{~g}, 92.9 \%$. M.P.: $265.9-272.2^{\circ} \mathrm{C}$. Anal. Calcd. for $\mathrm{Zn}$ $\left(\mathrm{C}_{34} \mathrm{H}_{36} \mathrm{~N}_{4} \mathrm{O}_{7} \mathrm{~S}\right)$ : C, 57.51; H, 5.11; N.7.89; Found: C, 57.78; H, 5.39; N, 8.39\%. IR (KBr disk, $\mathrm{cm}^{-1}$ ): 3443 (s), 1606 (s), 1098 (m), $992(\mathrm{w}), 669(\mathrm{~m}) .{ }^{1} \mathrm{H}$ NMR $\left(\mathrm{CD}_{2} \mathrm{Cl}_{2}, \delta\right): 8.12$ (d, $1 \mathrm{H}, J$ $=6 \mathrm{~Hz}, \mathrm{Ar}-\mathrm{H}), 7.40(\mathrm{t}, 1 \mathrm{H}, J=6 \mathrm{~Hz}, \mathrm{Ar}-\mathrm{H}), 7.24(\mathrm{~d}, 2 \mathrm{H}, J=$ $9 \mathrm{~Hz}, \mathrm{Ar}-\mathrm{H}), 6.95$ (d \& t, $2 \mathrm{H}, J=7 \mathrm{~Hz}, \mathrm{Ar}-\mathrm{H}), 6.71(\mathrm{~d}, 2 \mathrm{H}$, $J=9 \mathrm{~Hz}, \mathrm{Ar}-\mathrm{H}), 3.62\left(\mathrm{~s}, \mathrm{OCH}_{3}, 3 \mathrm{H}\right), 2.53\left(\mathrm{~s}, 3 \mathrm{H}, \mathrm{SCH}_{3}\right)$, $2.19\left(\mathrm{~s}, 3 \mathrm{H}, \mathrm{H}_{3} \mathrm{C}-\mathrm{C}=\mathrm{N}\right) .{ }^{13} \mathrm{C} \mathrm{NMR}\left(\mathrm{CD}_{2} \mathrm{Cl}_{2}, \delta\right): 172.33$, $164.78,162.19,160.56,133.10,130.39,129.82,128.40,118.85$, 


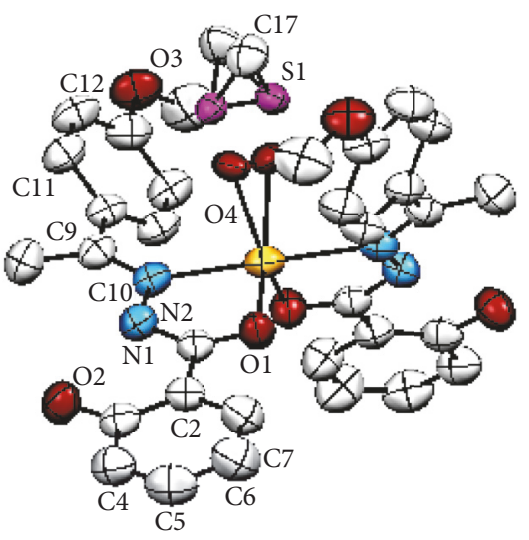

(a)

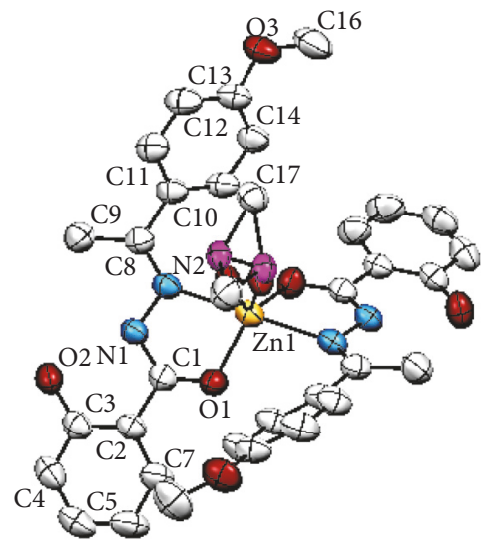

(b)

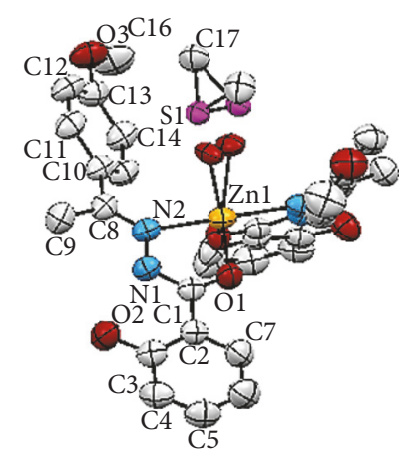

(c)

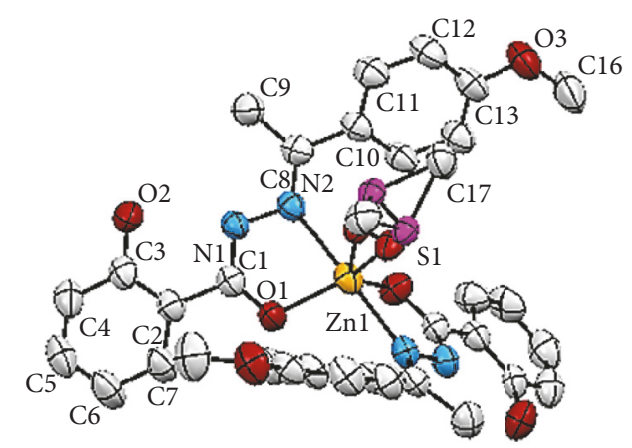

(d)

Figure 5: Molecular structure of bis-[(E)-2-hydroxy- $N^{\prime}-\{1-(4-$ methoxyphenyl)ethylidene $\}$ benzohydrazido]dimethylsulfoxidezinc(II) complex in different angles.

$117.33,117.07,114.36,54.02,41.41,18.62 . \mathrm{UV}-\mathrm{Vis}$ [DCM, $\lambda_{\max }$ ]: $345 \mathrm{~nm}$.

\section{Result and Discussion}

3.1. Synthesis and Characterization. Hydrazone Schiff base L1 was successfully synthesized through condensation reaction between salicylhydrazide and $4^{\prime}$-methoxyacetophenone under reflux for 24 hours at $75^{\circ} \mathrm{C}$. The color remained unchanged even after the addition of hot ethanolic salicylhydrazide into ethanolic solution of $4^{\prime}$-methoxyacetophenone with stirring and heating. A white color precipitate started to form after 12 hours with the yield of $75 \%$. However, L1 was not able to be analyzed using GC-MS due to low solubility in DCM. Despite low solubility in DCM, the molecular structure of L1 has been reported by Qiu and coworkers in 2006 [18]. The ligand, L1, was then reacted with zinc(II) acetate under open air reflux condition for 28 hours. Upon completion of the reaction, the dark yellow solution was filtered, and the $\mathrm{Zn}$ (II) complex appeared as tiny pale yellow crystal after a week.

Based on the IR spectra of L1 (see Fig. S1 in Supplementary Material available online at https://doi.org/10.1155/2017/ 7520640 ) and $\mathrm{Zn}$ (II) complex (Figure 2), the absence of the $v(\mathrm{~N}-\mathrm{H})$ and $v(\mathrm{C}=\mathrm{O})$ peak in the IR spectrum of $\mathrm{Zn}(\mathrm{II})$ complex indicates enolization of keto group in L1, which coordinated to the $\mathrm{Zn}$ metal center through enolate oxygen. This is supported by the appearance of new band attributed to $v(\mathrm{C}-\mathrm{O})$ at $1098 \mathrm{~cm}^{-1}$ after the complexation reaction [19]. However, the changes of $v(\mathrm{C}=\mathrm{N})$ chemical shift from 1605 to $1606 \mathrm{~cm}^{-1}$ in the IR spectra were rather insignificant after the complexation. This result is, indeed, parallel to the finding from Tay et al., [5] where the IR frequency of $\mathrm{C}=\mathrm{N}$ was also shifted by only $2 \mathrm{~cm}^{-1}$ from $1621 \mathrm{~cm}^{-1}$ to $1619 \mathrm{~cm}^{-1}$ after their bis-2'-hydroxy Schiff base compound bound to $\mathrm{Zn}$ (II) metal center.

In fact, the IR data is supported by the UV-Vis result (Figure 3) where the $n \rightarrow \pi^{*}$ transition in $\mathrm{C}=\mathrm{N}$ bond shifted from $320 \mathrm{~nm}$ to $345 \mathrm{~nm}$ after binding to the $\mathrm{Zn}$ metal center. The bathochromic shift is due to the backbonding from $\mathrm{Zn}$ to the $\mathrm{C}=\mathrm{N}$ bond in $\mathbf{L} \mathbf{1}$ and subsequently weakened the bond energy of $\mathrm{C}=\mathrm{N}$.

The ${ }^{1} \mathrm{H}$ NMR spectrum of $\mathrm{Zn}$ (II) complex (Figure 4) also shows some differences compared to L1 (see Fig. S2). A broad signal at $11.81 \mathrm{ppm}$ and a singlet present at $11.28 \mathrm{ppm}$ in the ${ }^{1} \mathrm{H}$ NMR spectrum of $\mathbf{L} \mathbf{1}$ are assigned to the $\mathrm{N}$ $\underline{\mathrm{H}}$ of azomethine and phenolic proton in $\mathbf{L} \mathbf{1}$, respectively. These two NMR resonances indicate that $\mathbf{L} \mathbf{1}$ is of keto form. This is also supported by the IR spectrum of L1 with the 
TABLE 1: Summary of crystallographic and refinement data for $\mathrm{Zn}$ (II) complex.

\begin{tabular}{lc}
\hline Compound & Zn(II) complex \\
\hline Crystal system & Monoclinic \\
$a(\AA)$ & $24.5646(10)$ \\
$b(\AA)$ & $8.7981(3)$ \\
$c(\AA)$ & $15.7993(6)$ \\
$\alpha(\AA)$ & 90.00 \\
$\beta(\AA)$ & $96.6410(3)$ \\
$\gamma(\AA)$ & 90.00 \\
Volume $\left(\AA^{3}\right)$ & $3391.7(2)$ \\
$Z$ & 8 \\
Density $\left(\mathrm{Mg} / \mathrm{m}^{3}\right)$ & 1.726 \\
Absorption coefficient $\left(\mathrm{mm}^{-1}\right)$ & 1.482 \\
$\Theta$ range for data collection & $2.46-24.20$ \\
Reflections collected & 3924 \\
Independent reflections & 2565 \\
Data/restraints/parameter & $3924 / 0 / 231$ \\
Final $R$ indices & $R 1=0.0913$ \\
& $w R 2=0.25$ \\
$R$ indices (all data) & $R 1=0.1263$ \\
& $w R 2=0.2739$ \\
\hline
\end{tabular}

presence of $v(\mathrm{~N}-\mathrm{H})$ and $v(\mathrm{C}=\mathrm{O})$ at 3270 and $1604 \mathrm{~cm}^{-1}$, respectively. The two NMR resonances at 11.81 and $11.28 \mathrm{ppm}$ disappeared after complexation reaction, indicating that the structure of $\mathbf{L 1}$ changed from keto to enol conformation and the $\mathrm{O}$ atom from phenolic group has bound to the $\mathrm{Zn}$ metal center. On top of these, a new peak at $2.55 \mathrm{ppm}$ was found in the ${ }^{1} \mathrm{H}$ NMR spectrum of $\mathrm{Zn}$ (II) complex. Based on the integration, this singlet is the combination of the protons from dimethyl sulfoxide (DMSO) and enolic proton after forming the complex. The presence of DMSO is due to the solvent used during the recrystallization process, and the crystal data also confirms that a DMSO molecule is bound to $\mathrm{Zn}$ metal center.

The crystallographic molecular structure of bis-[(E)-2hydroxy- $N^{\prime}-\{1$-(4-methoxyphenyl)ethylidene\}benzohydrazido]dimethylsulfoxidezinc(II) complex is shown in Figure 5. The molecular structure is shown in different angles [Figures 5(a)-5(d)] for better clarity to show each coordination to $\mathrm{Zn}$ metal center. The crystal data is presented in Table 1 and selected bond lengths as well as bond angles are shown in Table 2. The complex crystallizes in monoclinic system and the molecule is believed to exhibit a distorted trigonal bipyramidal geometry. The molecular formula of the $\mathrm{Zn}$ (II) complex conforms to the $\mathrm{C}, \mathrm{H}$, and $\mathrm{N} \%$ which were found from the elemental analysis.

The bond distance for $\mathrm{Zn1-N1}$ is $2.209 \AA$ whereas the bond length for Zn1-O1 is $1.974 \AA$. The longer bond length in $\mathrm{Zn}-\mathrm{N}$ compared to $\mathrm{Zn}-\mathrm{O}$ indicates that the $\mathrm{Zn}-\mathrm{N}$ bond is weaker than $\mathrm{Zn}-\mathrm{O}$. This is due to the stronger trans-effect of $\mathrm{C}=\mathrm{N}$ bond compared to that of the $\mathrm{C}-\mathrm{O}$ bond. The reason for that is because $\mathrm{C}=\mathrm{N}$ contains $\pi$-bond which plays an
TABLE 2: Selected bond lengths $(\AA)$ and bond angles $\left(^{\circ}\right)$ for $\mathrm{Zn}(\mathrm{II})$ complex.

\begin{tabular}{lccc}
\hline Bond lengths & $\AA$ & Bond angles & $\left(^{\circ}\right)$ \\
\hline Zn1-N1 & 2.209 & O1-Zn1-N1 & 102.35 \\
Zn1-O1 & 1.974 & O1-Zn-O1 & 111.0 \\
Zn1-O1AA & 2.049 & N1-Zn-N1 & 179.8 \\
C9-N1 & 1.291 & & \\
N1-N2 & 1.405 & & \\
N2-C1AA & 1.317 & & \\
C1AA-O1 & 1.276 & & \\
\hline
\end{tabular}

important role in trans-effect. Besides the two $\mathbf{L} \mathbf{1}$ chelating ligands, a disordered DMSO molecule [Figures 5(a) and 5(c)] was found to coordinate to the $\mathrm{Zn}$ metal center via oxygen atom. The bond distance $\mathrm{Zn}-\mathrm{O} 4$ is $2.049 \AA$. Meanwhile the interatomic distance for C8-N2, N1-N2, N1-C1, and C1-O1 in the azomethine group $(-\mathrm{C}=\mathrm{N}-\mathrm{N}=\mathrm{C}-\mathrm{O})$ moiety is $1.294,1.403$, 1.317 , and $1.278 \AA$, respectively. The longer bond lengths of C8$\mathrm{N} 2$ and $\mathrm{N} 1-\mathrm{C} 1$ than the normal $\mathrm{C}=\mathrm{N}$ bond $(1.279 \AA)$ and the shorter bond length for N1-N2 than the previously reported data (1.420 $\AA$ ) [20] suggested the presence of a conjugation system along $\mathrm{C}=\mathrm{N}-\mathrm{N}=\mathrm{C}$ moiety. This indicates that the N1$\mathrm{N} 2$ bond became stronger, in parallel with the data obtained in the IR in which the $v(\mathrm{~N}-\mathrm{N})$ underwent positive shift in the IR spectrum of the complex. Moreover, the bond length for C1-O1 is shorter than the normal C-O bond length (1.5 $\AA$ ) due to keto-enol tautomerization $[2,3]$.

The dihedral angle between O1-Zn1-N1 planes of two L1 chelating ligands is $102.35^{\circ}$. The bond angles for O1-Zn-O1 and $\mathrm{N} 1-\mathrm{Zn}-\mathrm{N} 1$ are $111.0^{\circ}$ and $179.8^{\circ}$, respectively. The bond angle for the $\mathrm{O} 1-\mathrm{Zn}-\mathrm{O} 1$ deviates from the ideal bond angle for square planar $\left(180^{\circ}\right)$. This can be explained by the presence of the disordered DMSO. The bond angles and the X-ray structure observed suggested that the chelating ligands which coordinate to the zinc metal ion are perpendicular to each other, parallel to the description of square planar.

3.2. Antibacterial Screening. The antibacterial activity of hydrazone Schiff base $\mathbf{L} 1$ and its $\mathrm{Zn}$ (II) complex was examined using disc diffusion method and the results were tabulated in Table 3 and Figure 6. The results show that both L1 and its $\mathrm{Zn}$ (II) complex are considered nontoxic to grampositive (Bacillus cereus) and gram-negative (Escherichia coli) bacteria as there is no significant difference in the inhibition areas with increasing concentration of both $\mathbf{L} \mathbf{1}$ and its $\mathrm{Zn}$ (II) complex; even the concentration was increased up to $800 \mathrm{ppm}$. The possible reason to this could be the absence of lipophilic group such as long carbon chains in both structures. Birnie and coworkers [21] reported the use of long carbon chains substituents, such as $\mathrm{C}_{8} \mathrm{H}_{17}$ and $\mathrm{C}_{10} \mathrm{H}_{21}$, in enhancing the antibacterial activity.

\section{Conclusion}

The synthesis and molecular structure of 5-coordinated bis[(E)-2-hydroxy- $N^{\prime}$-\{1-(4-methoxyphenyl)ethylidene\}benzohydrazido]dimethylsulfoxidezinc(II) complex were reported. 
TABLE 3: Results of antibacterial activity for hydrazone Schiff base, L1, and its $\mathrm{Zn}(\mathrm{II})$ complex.

\begin{tabular}{lcccc}
\hline \multirow{2}{*}{ Conc. (ppm) in DCM } & \multicolumn{3}{c}{$\begin{array}{c}\text { Bacillus cereus ATCC 33019 } \\
\text { Diameter of inhibition zone, mm (average of triplicates) }\end{array}$} \\
& L1 & Zn(II) complex & L1 & Zn(II) complex \\
\hline 0 & 10.0 & 10.0 & 10.0 & 10.0 \\
200 & 9.5 & 9.5 & 11.0 & 9.5 \\
400 & 10.0 & 9.0 & 12.0 & 11.5 \\
800 & 10.0 & 10.0 & 12.0 & 10.0 \\
\hline
\end{tabular}

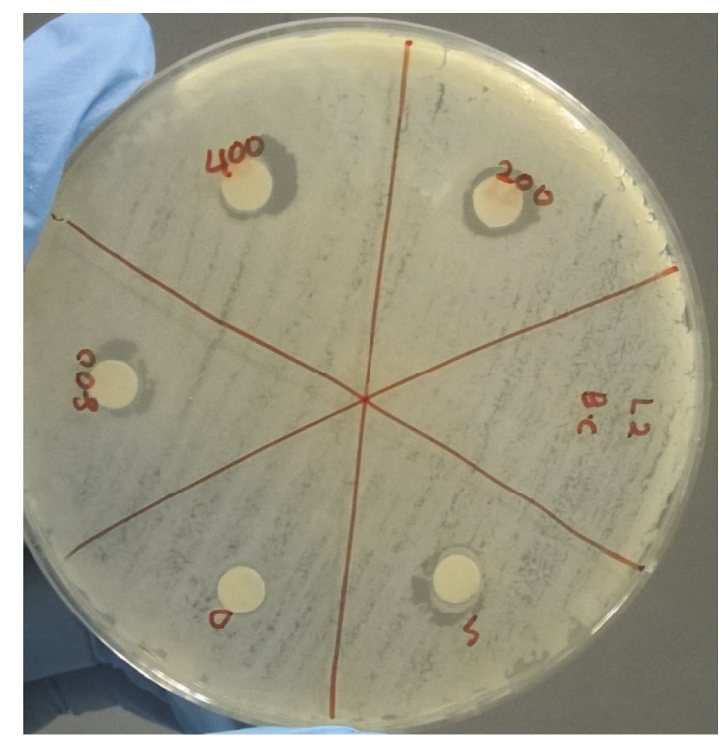

(a)

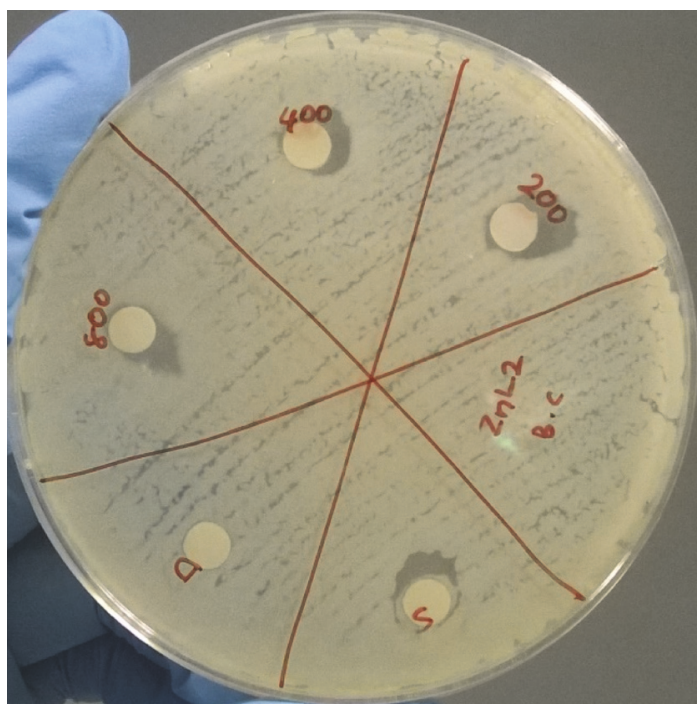

(c)

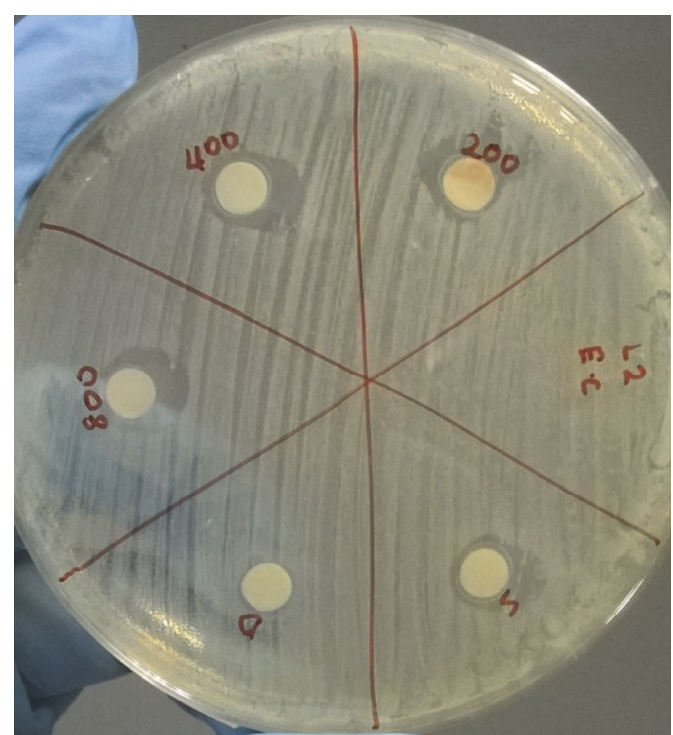

(b)

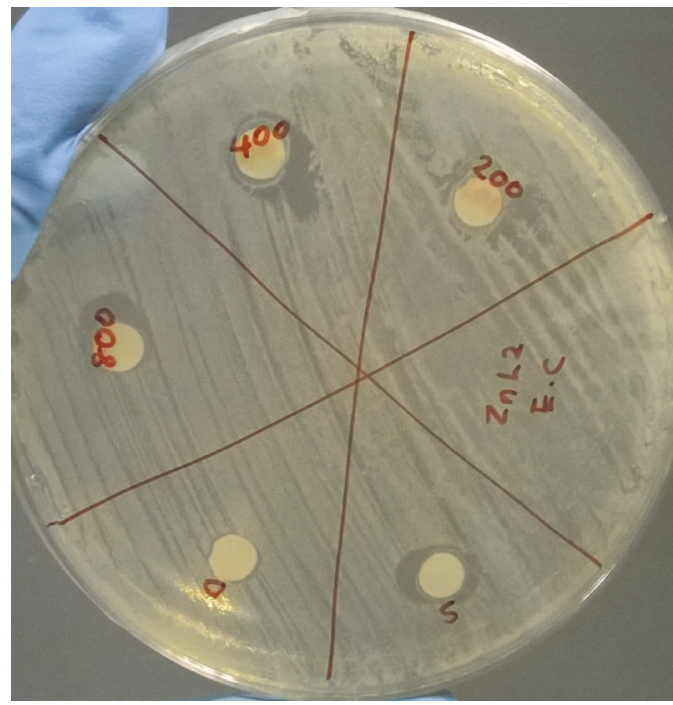

(d)

FIgure 6: Antibacterial activity of L1 (a and b) and its Zn(II) complex (c and d); Bacillus cereus (a and c) and Escherichia coli (b and d).

The molecular structure and formula of the $\mathrm{Zn}$ (II) complex are in agreement with the results from $\mathrm{CHN}$ elemental analysis and ${ }^{1} \mathrm{H}$ NMR spectroscopy. In addition, the bathochromic shift of $\mathrm{C}=\mathrm{N}$ wavelength in absorption spectra indicates the binding of nitrogen atom from $\mathrm{C}=\mathrm{N}$ to $\mathrm{Zn}$ (II) metal center. From the result of antibacterial study, both $\mathbf{L} \mathbf{1}$ and its $\mathrm{Zn}$ (II) complex are considered nontoxic to both gram-positive and gram-negative bacteria. 


\section{Conflicts of Interest}

The authors declare that there are no conflicts of interest regarding the publication of this paper.

\section{Acknowledgments}

The authors are grateful to the research funding from Malaysian Ministry of Higher Education under Research Acculturation Grant Scheme (RAGS) with no. RAGS/ ST01(1)/1038/2013(05).

\section{References}

[1] G. Dutkiewicz, B. Narayana, S. Samshuddin, H. S. Yathirajan, and M. Kubicki, "Synthesis and crystal structures of two new Schiff base hydrazones derived from biphenyl-4carbohydrazide," Journal of Chemical Crystallography, vol. 41, no. 10, pp. 1442-1446, 2011.

[2] P. Fita, E. Luzina, T. Dziembowska et al., "Keto-enol tautomerism of two structurally related Schiff bases: Direct and indirect way of creation of the excited keto tautomer," Chemical Physics Letters, vol. 416, no. 4-6, pp. 305-310, 2005.

[3] S. R. Kelode and P. R. Mandlik, "Synthesis, characterization, thermal and antibacterial studies of cobalt(II), nickel(II), copper(II) and zinc(II) complexes of hydrazone Schiff base," International Journal of Chemical and Pharmaceutical Sciences, vol. 3, no. 3, pp. 30-33, 2012.

[4] H. H. Monfared, O. Pouralimardan, and C. Janiak, "Synthesis and spectral characterization of hydrazone schiff bases derived from 2,4-dinitrophenylhydrazine. Crystal structure of salicylaldehyde-2,4-dinitrophenylhydrazone," Zeitschrift fur Naturforschung -Section B Journal of Chemical Sciences, vol. 62, pp. 717-720, 2007.

[5] M. G. Tay, Z. Ngaini, M. A. Mohd Arif et al., "Complexation of bis-2-(benzylideneamino)phenol to cobalt(II) and zinc(II), and their spectroscopic studies," Borneo Journal of Resource Science and Technology, vol. 3, no. 1, pp. 26-34, 2013.

[6] Z. A. Siddiqi, M. Shahid, M. Khalid, and S. Kumar, "Antimicrobial and SOD activities of novel transition metal ternary complexes of iminodiacetic acid containing $\alpha$-diimine as auxiliary ligand," European Journal of Medicinal Chemistry, vol. 44, no. 6, pp. 2517-2522, 2009.

[7] L. S. Kumar, K. S. Prasad, and H. D. Revanasiddappa, "Synthesis, characterization, antioxidant, antimicrobial, DNA binding and cleavage studies of mononuclear $\mathrm{Cu}(\mathrm{II})$ and Co(II) complexes of 3-hydroxy- $N^{\prime}$-(2-hydroxybenzylidene)-2naphthohydrazide," European Journal of Chemistry, vol. 2, no. 3, pp. 394-403, 2011.

[8] S. R. Yaul, A. R. Yal, G. B. Pethe, and A. S. Aswar, "Synthesis and characterization of transition metal complexes with $\mathrm{N}$, O-chelating hydrazone Schiff base ligand," American-Eurasian Journal of Scientific Research, vol. 4, no. 4, pp. 229-234, 2009.

[9] M. Neelamma, P. V. Rao, and G. H. Anuradha, "Synthesis and structural studies on transition metal complexes derived from 4-hydroxy-4-methyl-2-pentanone-1H-benzimidazol-2yl-hydrazone," E-Journal of Chemistry, vol. 8, no. 1, pp. 29-36, 2011.

[10] M. Franks, A. Gadzhieva, L. Ghandhi et al., "Five coordinate $\mathrm{M}(\mathrm{II})$-diphenolate $[\mathrm{M}=\mathrm{Zn}(\mathrm{II}), \mathrm{Ni}(\mathrm{II})$, and $\mathrm{Cu}(\mathrm{II})]$ Schiff base complexes exhibiting metal-and ligand-based redox chemistry," Inorganic Chemistry, vol. 52, no. 2, pp. 660-670, 2013.
[11] E. Szłyk, A. Wojtczak, A. Surdykowski, and M. Goździkiewicz, "Five-coordinate $\operatorname{zinc}(\mathrm{II})$ complexes with optically active Schiff bases derived from (1R,2R)-(-)cyclohexanediamine: $\mathrm{X}$-ray structure and CP MAS NMR characterization of [cyclohexylenebis(5-chlorosalicylideneiminato)zinc(II) pyridine] and [cyclohexylenebis(5-bromosalicylideneiminato)zinc(II)pyridine]," Inorganica Chimica Acta, vol. 358, no. 3, pp. 467-475, 2005.

[12] J. M. Newman, C. A. Bear, T. W. Hambley, and H. C. Freeman, "Structure of bis(glycinato)zinc(II) monohydrate, a fivecoordinate zinc(II) complex," Acta Crystallographica Section C Crystal Structure Communications, vol. C46, pp. 44-48, 1990.

[13] X.-W. Song, X.-J. Gao, H.-X. Liu, H. Chen, and C.-N. Chen, "Synthesis and characterization of a supramolecular assembly based on a pyridyl-functionalized [FeFe]-hydrogenase mimic and zinc tetraphenylporphyrin," Inorganic Chemistry Communications, vol. 70, pp. 1-3, 2016.

[14] W. Che, T. Yu, D. Jin et al., "A simple oxazoline as fluorescent sensor for $\mathrm{Zn}^{2+}$ in aqueous media," Inorganic Chemistry Communications, vol. 69, pp. 89-93, 2016.

[15] Siemens SMART \&amp; SAINT. Siemens analytical X-ray instruments inc., Madison, Wisconsin, USA. 1996.

[16] G. M. Sheldrick, "SHELXL-97 and SHELXS-97," 1997, University of Göttingen, Germany.

[17] A. A. Osowole, "Synthesis, spectroscopic characterization, invitro antibacterial and antiproliferative activities of some metal (II) complexes of 3,4-dihydronaphthalen-1(2H)-one Schiff base," Experimental and Clinical Sciences, vol. 11, pp. 338-345, 2012.

[18] X.-Y. Qiu, Q.-Y. Luo, S.-L. Yang, and W.-S. Liu, “(E)-2-Hydroxy$N^{\prime}$-[1-(4-methoxyphenyl)-ethylidene]benzohydrazide," Acta Crystallographica Section E: Structure Reports Online, vol. E62, no. 10, pp. o4291-o4292, 2006.

[19] M. D. Sagolsem and M. S. Akojiam, "Synthesis and studies of nickel(II) and cobalt(II) complexes of furfural isonicotinoyl hydrazone (FINH)," in Proceedings of the, vol. 2, pp. 290-296, 2012.

[20] F. H. Allen, O. Kennard, D. G. Watson, L. Brammer, A. G. Orpen, and R. Taylor, "Tables of bond lengths determined by X-ray and neutron diffraction. Part 1. Bond lengths in organic compounds," Journal of the Chemical Society, Perkin Transactions 2, no. 12, pp. S1-S19, 1987.

[21] C. R. Birnie, D. Malamud, and R. L. Schnaare, "Antimicrobial evaluation of $N$-alkyl betaines and $N$-alkyl- $N, N$ dimethylamine oxides with variations in chain length," Antimicrobial Agents and Chemotherapy, vol. 44, no. 9, pp. 2514-2517, 2000 . 

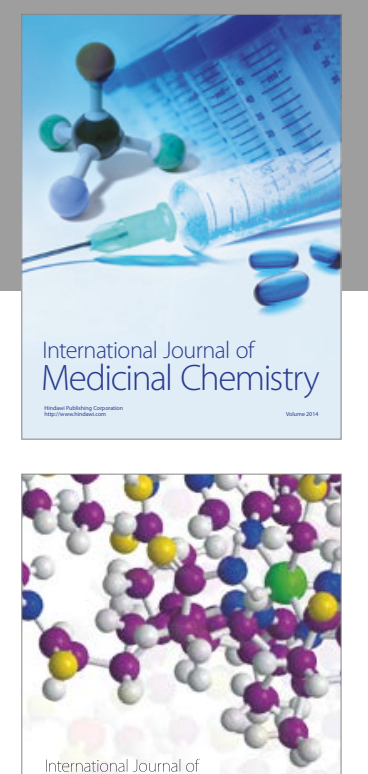

Carbohydrate Chemistry

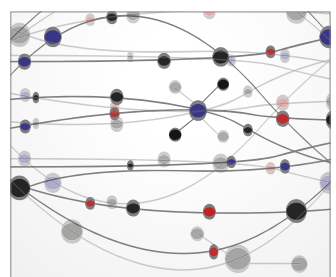

The Scientific World Journal
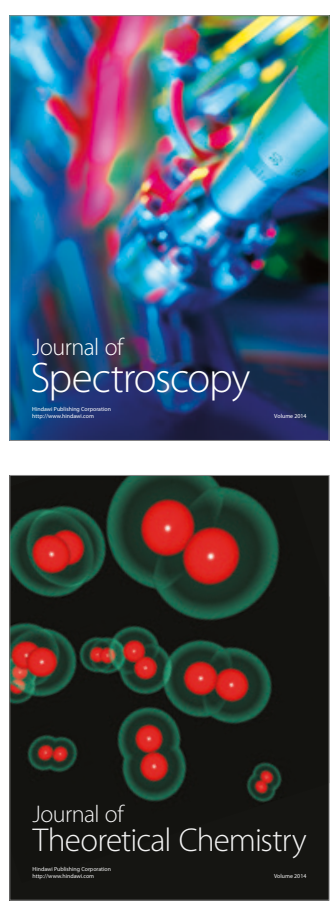
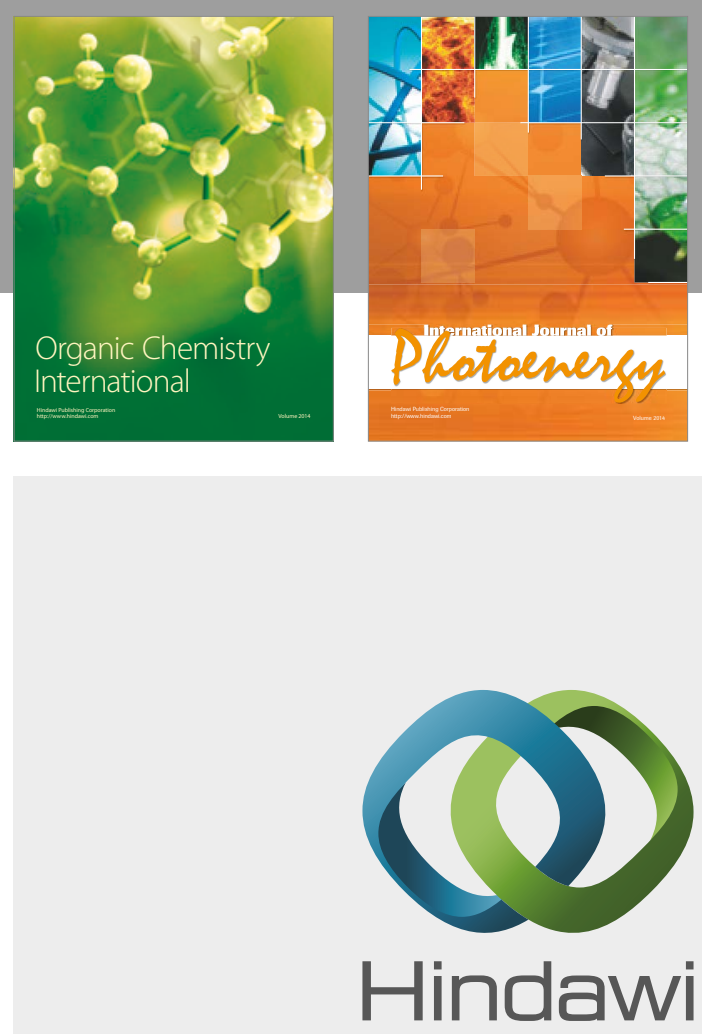

Submit your manuscripts at

https://www.hindawi.com

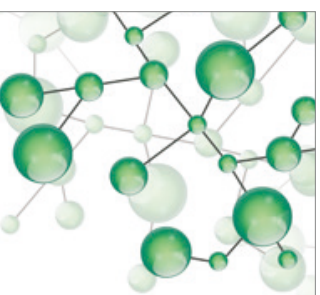

International Journal of

Inorganic Chemistry

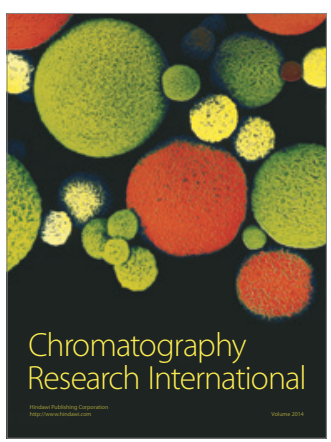

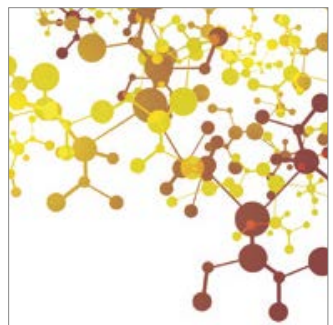

Applied Chemistry
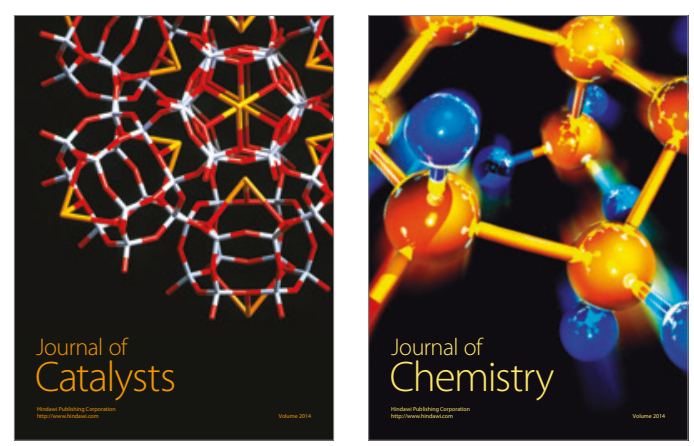
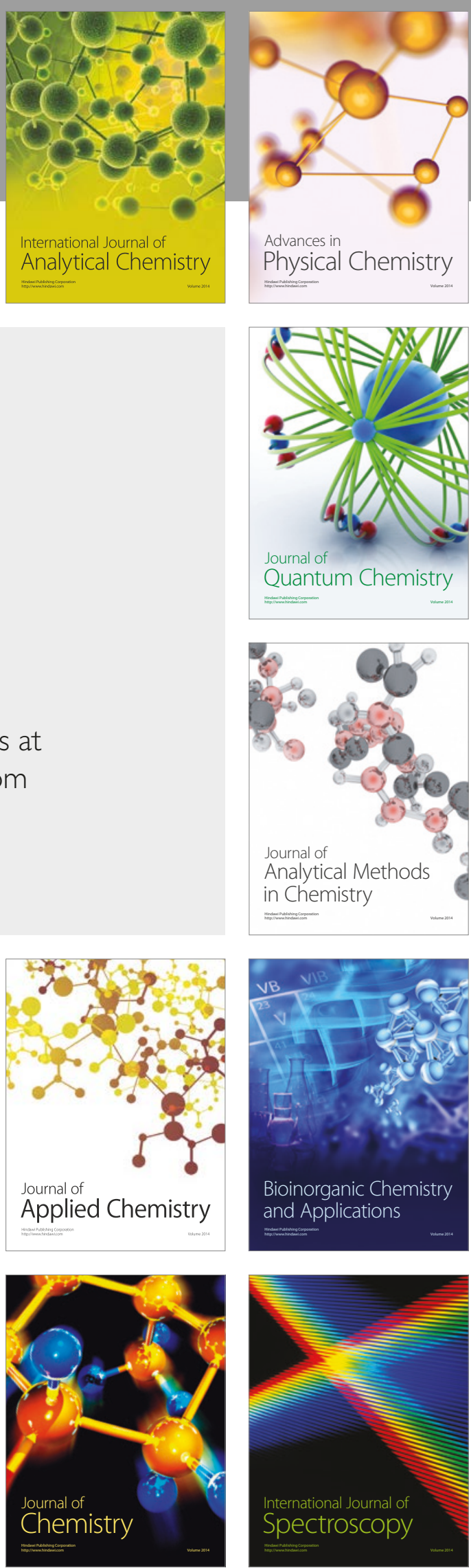